\title{
PENGARUH POLA MAKAN, USIA PADA IBU BEKERJA TERHADAP KEBERHASILAN ASI EKSLUSIF DI PUSKESMAS LANGGA PAYUNG KEC. SUNGAI KANAN KAB. LABUHAN BATU SELATAN TAHUN 2020
}

\author{
Debora Lestari Simamora \\ Universitas Imelda Medan, Indonesia
}

\begin{abstract}
Article Info
Article history:

Received Sep 23, 2020

Revised Sep 24, 2020

Accepted Sep 25, 2020

ABSTRACT

Currently, the participation rate of female workers has increased from $48.63 \%$ to $49.52 \%$ with a total of 81.5 million people. There are still many breastfeeding mothers who work so that they cannot provide exclusive breastfeeding to their babies or are not optimal in giving exclusive breastfeeding. Factors that are thought to influence the success of exclusive breastfeeding are diet and maternal age. The purpose of this study was to determine the effect of diet and age on working mothers on the success of exclusive breastfeeding. This research is an analytical and quantitative study with a case control design. The research was conducted at the Langga Payung Public Health Center, Sungai Kanan District, Labuhan Batu Selatan Regency. The study population was 30 people and divided into 2 sample groups, namely 15 cases and 15 control groups. Data analysis was performed univariate, bivariate using the chi-square test, while multivariate analysis used multiple logistic regression tests with a confidence level of 95\% ( $\square=0,05$ ). Based on the results of the study, it shows that diet affects the success of exclusive breastfeeding at Langga Payung Health Center, $\mathrm{p}=$ $0.008<0.05$. The dietary variable has a value of $\operatorname{Exp}(\mathrm{B}) / \mathrm{OR}=13,000$, which means that mothers who work with a regular diet have a 13 times higher chance of succeeding in giving exclusive breastfeeding than respondents with irregular eating patterns. Age variable has no effect on the success of exclusive breastfeeding, $\mathrm{p}=0.108>0.05$.
\end{abstract}

This is an open access article under the CC BY-SAlicense.

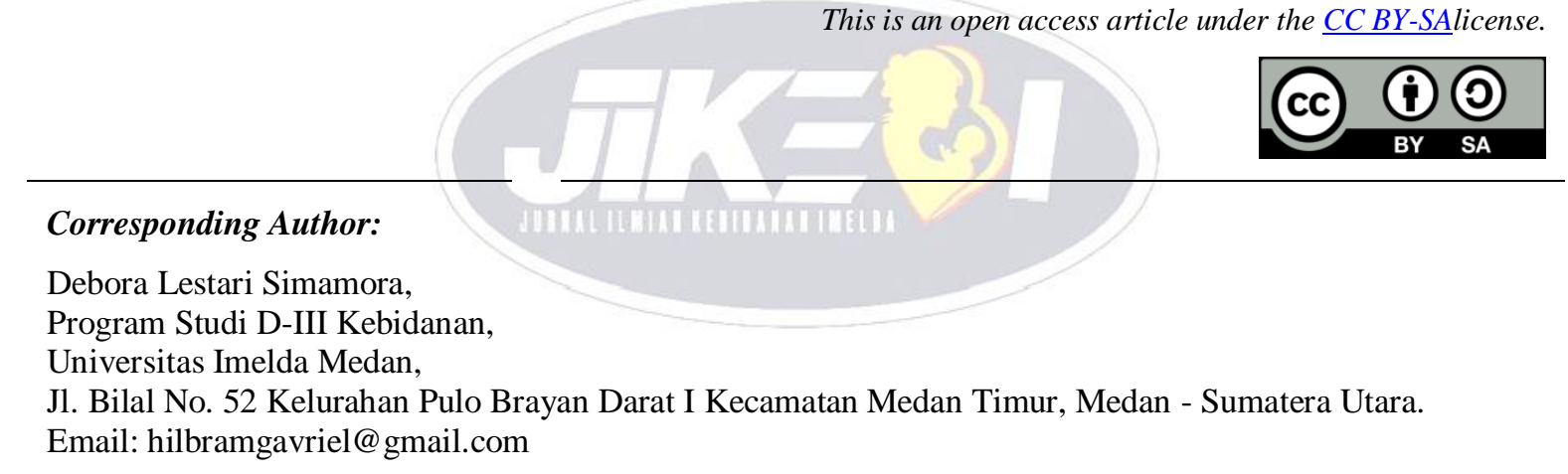

\section{INTRODUCTION}

Seribu hari pertama kehidupan (1000 HPK) merupakan masa awal proses kehidupan manusia yang dimulai sejak masa kehamilan, masa bayi hingga anak berusia 2 tahun. Pada periode ini terjadi proses pembentukan dan perkembangan yang sangat cepat, sehingga menentukan status kesehatan fisik, kesehatan dan kecerdasan anak. Jika gizi tidak diberikan secara optimal, maka anak akan menjadi lebih pendek, daya tahan tubuh tidak optimal, perkembangan kognitif menjadi tidak optimal, peningkatan risiko obesitas dan penyakit degeneratif. Pada jangka panjang berdampak negatif terhadap kualitas generasi bangsa yang akan datang (Rahmawati dan Wirawan, 2016). 
Data Badan Kesehatan Dunia (WHO, 2016) menunjukkan rata-rata angka pemberian ASI eksklusif di dunia baru berkisar 38 persen. Jika dibandingkan dengan target WHO sebesar 50\%, maka angka tersebut masih jauh dari target. Indonesia menduduki peringkat ke tiga terbawah dari 51 negara di dunia yang mengikuti penilaian status kebijakan dan program pemberian makan bayi dan anak. Hal ini menunjukkan, pemberian ASI sebagai makanan pertama bayi masih kurang. Pemberian ASI eksklusif dan MP-ASI yang benar dapat mencegah anak mengalami gizi kurang, buruk dan tumbuh pendek (stunting) (Paramita, 2016).

Pemberian ASI eksklusif secara baik, sekitar 6 bulan pertama kelahiran akan berdampak sangat positif bagi tumbuh kembang bayi baik secara emosional maupun fisik. Bayi akan tumbuh lebih sehat dengan sistem imun yang sempurna dari air susu ibu (ASI), karena ASI mampu memberi perlindungan yang sempurna bagi bayi yang baru lahir (Amiruddin, 2016).

Ada beberapa faktor yang dapat mempengaruhi pemberian ASI eksklusif yaitu faktor internal dan faktor eksternal. Faktor internalnya antara lain adalah pendidikan ibu, pengetahuan ibu, sikap dan perilaku ibu, faktor fisik ibu serta faktor emosional. Sedangkan faktor eksternalnya adalah ibu yang bekerja, jam kerja ibu, dukungan suami, dukungan tempat kerja, pemberian makanan pralaktal dan pemberian susu formula (Setiowati, 2016).

Berdasarkan latar belakang masalah yang telah disusun maka rumusan masalah yang dapat ditarik adalah apakah ada Pengaruh Pola Makan dan Usia pada Ibu Bekerja Terhadap Keberhasilan ASI Eksklusif di Puskesmas Langga Payung Kec. Sungai Kanan Kab. Labuhan Batu Selatan?

Adapun tujuan penelitian ini adlah Untuk mengetahui Pengaruh Pola Makan dan Usia pada Ibu Bekerja Terhadap Keberhasilan ASI Eksklusif di Puskesmas Langga Payung Kec. Sungai Kanan Kab. Labuhan Batu Selatan. Hasil penelitian ini dapat dijadikan kontribusi terhadap pengembangan ilmu kebidanan serta masukan informasi pendidikan kesehatan tentang pentingnya menjaga Pola Makan dan Usia Pada Ibu Bekerja Keberhasilan ASI Eksklusif.

\section{RESEARCH METHOD}

Penelitian ini merupakan penelitian analitik dan bersifat kuantitatif dengan rancangan kasus kontrol (case control), dimana meneliti peristiwa yang telah terjadi dan melihat ke belakang untuk mengetahui faktor-faktor yang dapat menimbulkan kejadian tersebut untuk mengungkap faktor yang melatarbelakangi Keberhasilan ASI Eksklusif. Waktu Penelitian dilaksanakan dari bulan Maret 2020 sampai dengan bulan Juli 2020. Tempat penelitian dilaksanakan di Puskesmas Langga Payung Sungai Kanan Kab. Labuhan Batu Selatan.

\section{RESULTS AND ANALYSIS}

\subsection{Hasil}

\section{Analisis Univariat}

\section{Pola Makan}

Berdasarkan hasil penelitian, pola makan responden dapat dilihat pada tabel berikut ini.

Tabel 1. Distribusi Responden Berdasarkan Pola makan di Puskesmas Langga Payung Kecamatan Sungai Kanan Kabupaten Labuhan Batu Selatan

\begin{tabular}{cccccc}
\hline \multirow{2}{*}{ No } & \multirow{2}{*}{ Pola makan } & \multicolumn{2}{c}{ Kelompok Kasus } & \multicolumn{2}{c}{ Kelompok Kontrol } \\
\cline { 3 - 6 } & & Jumlah & $\mathbf{\%}$ & Jumlah & \% \\
\hline 1. & Teratur & $\mathbf{5}$ & $\mathbf{3 3 , 3}$ & $\mathbf{1 3}$ & $\mathbf{8 6 , 7}$ \\
\hline 2. & Tidak teratur & 10 & 66,7 & 2 & 13,3 \\
\hline & Jumlah & $\mathbf{1 5}$ & $\mathbf{1 0 0 , 0}$ & $\mathbf{1 5}$ & $\mathbf{1 0 0 , 0}$ \\
\hline
\end{tabular}

Tabel di atas menunjukkan bahwa mayoritas responden pada kelompok kasus dengan pola makan tidak teratur yaitu 10 orang $(66,7 \%)$, sedangkan pada kelompok kontrol mayoritas responden dengan pola makan teratur yaitu 13 orang $(86,7 \%)$.

2. Usia

Berdasarkan hasil penelitian, usia responden dapat dilihat pada tabel berikut ini.

Tabel 2. Distribusi Responden Berdasarkan Usia di Puskesmas Langga Payung Kecamatan Sungai Kanan Kabupaten Labuhan Batu Selatan

\begin{tabular}{|c|c|c|c|c|c|}
\hline \multirow{2}{*}{ No } & \multirow{2}{*}{ Usia } & \multicolumn{2}{|c|}{ Kelompok Kasus } & \multicolumn{2}{|c|}{ Kelompok Kontrol } \\
\hline & & Jumlah & $\%$ & Jumlah & $\%$ \\
\hline 1. & Usia reproduksi sehat (20-35 tahun) & 6 & 40,0 & 13 & 86,7 \\
\hline 2. & Usia reproduksi tidak sehat ( $<20$ tahun dan $>35$ tahun) & 9 & 60,0 & 2 & 13,3 \\
\hline & Jumlah & 15 & $\mathbf{1 0 0 , 0}$ & 15 & 100,0 \\
\hline
\end{tabular}

Tabel di atas menunjukkan bahwa mayoritas responden pada kelompok kasus berusia reproduksi tidak sehat ( $<20$ tahun dan $>35$ tahun) yaitu 9 orang $(60,0 \%)$, pada kelompok kontrol mayoritas responden berusia reproduksi sehat (20-35 tahun) yaitu 13 orang $(86,7 \%)$. 


\section{Analisis Bivariat}

\section{Pengaruh Pola Makan terhadap Keberhasilan ASI}

Pengaruh pola makan terhadap keberhasilan ASI dapat dilihat pada tabel berikut.

Tabel 3. Tabel Silang Pengaruh Pola Makan terhadap Keberhasilan ASI di Puskesmas Langga Payung Kecamatan Sungai Kanan Kabupaten Labuhan Batu Selatan

\begin{tabular}{|c|c|c|c|c|c|c|c|c|c|}
\hline \multirow{3}{*}{ No } & \multirow{3}{*}{ Pola Makan } & \multicolumn{4}{|c|}{ Keberhasilan ASI } & \multirow{2}{*}{\multicolumn{2}{|c|}{ Jumlah }} & \multirow{3}{*}{ p-value } & \multirow{3}{*}{ OR } \\
\hline & & \multicolumn{2}{|c|}{ Tidak ASI Eksklusif } & \multicolumn{2}{|c|}{ ASI Eksklusif } & & & & \\
\hline & & $\mathbf{f}$ & $\%$ & $\mathbf{f}$ & $\%$ & f & $\%$ & & \\
\hline 1 & Teratur & 5 & 27,8 & 13 & 72,2 & 18 & 100,0 & \multirow{2}{*}{0,008} & \multirow{2}{*}{$\begin{array}{c}13,000 \\
(2,074-81,479)\end{array}$} \\
\hline 2 & Tidak teratur & 10 & 83,3 & 2 & 16,7 & 12 & 100,0 & & \\
\hline
\end{tabular}

Berdasarkan tabel di atas menunjukkan bahwa dari 18 responden dengan pola makan teratur mayoritas berhasil dalam memberikan ASI Eksklusif sebanyak 13 orang (72,2\%). Dari 12 responden dengan pola makan tidak teratur mayoritas tidak berhasil dalam memberikan ASI Eksklusif sebanyak 10 orang $(83,3 \%)$.

Hasil uji bivariat menggunakan Chi-Square diperoleh p-value sebesar 0,008 < 0,05 artinya terdapat pengaruh yang signifikan antara pola makan terhadap keberhasilan ASI di Puskesmas Langga Payung Kecamatan Sungai Kanan Kabupaten Labuhan Batu Selatan tahun 2020. Nilai Odds Ratio (OR) $=13,000$ $>1$ yang berarti bahwa variabel pola makan merupakan faktor risiko tidak berhasilnya pemberian ASI Eksklusif.

\section{Pengaruh Usia terhadap Keberhasilan ASI}

Pengaruh usia terhadap keberhasilan ASI dapat dilihat pada tabel berikut.

Tabel 4. Tabel Silang Pengaruh Usia terhadap Keberhasilan ASI di Puskesmas Langga Payung Kecamatan Sungai Kanan Kabupaten Labuhan Batu Selatan

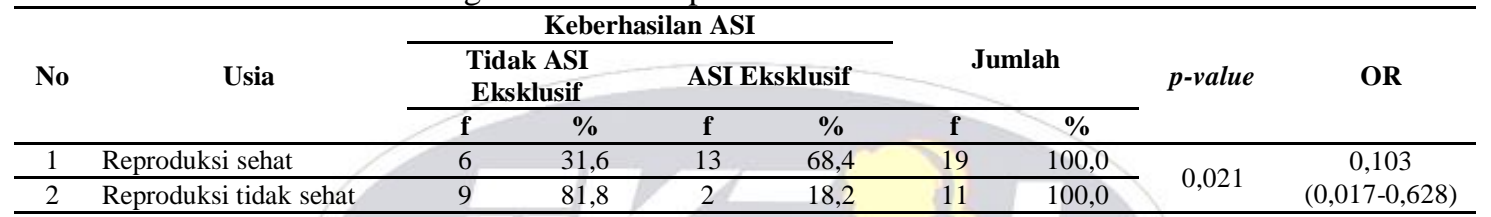

Berdasarkan tabel di atas menunjukkan bahwa dari 19 responden dengan usia reproduksi sehat (20-

35 tahun) mayoritas berhasil dalam memberikan ASI Eksklusif sebanyak 13 orang (68,4\%). Dari 11 responden dengan usia reproduksi tidak sehat ( $<20-\geq 35$ tahun) mayoritas tidak berhasil dalam memberikan ASI Eksklusif sebanyak 9 orang $(81,8 \%)$.

Hasil uji bivariat menggunakan Chi-Square diperoleh $p$-value sebesar 0,021 0,05 artinya terdapat pengaruh yang signifikan antara usia terhadap keberhasilan ASI di Puskesmas Langga Payung Kecamatan Sungai Kanan Kabupaten Labuhan Batu Selatan tahun 2020. Nilai Odds Ratio $(O R)=0,103<1$ yang berarti bahwa variabel usia merupakan faktor protektif keberhasilan pemberian ASI Eksklusif.

\section{Analisis Multivariat}

Analisis multivariat dilakukan untuk mengetahui faktor-faktor yang berpengaruh terhadap keberhasilan ASI Eksklusif secara bersamaan menggunakan uji regresi logistik ganda (multiple logistic regression) melalui beberapa langkah:

1) Melakukan pemilihan variabel yang potensial dimasukkan sebagai kandidat model. Variabel yang dipilih sebagai kandidat adalah variabel yang memiliki nilai signifikan.

2) Dalam pemodelan ini variabel kandidat yang memiliki nilai $p$-value $<0,25$ pada uji bivariat (uji chisquare) dimasukkan secara bersama-sama dalam uji multivariat.

3) Penggunaan kemaknaan statistik 0,25 sebagai persyaratan dalam uji regresi logistik berganda untuk memungkinkan variabel-variabel yang secara terselubung sesungguhnya secara substansi sangat penting dimasukkan ke dalam model multivariat.

4) Dari hasil uji bivariat, variabel yang dijadikan kandidat model pada uji regresi logistik berganda pada penelitian ini karena memiliki nilai signifikan $<0,25$ yaitu sebanyak 2 variabel terdiri dari pola makan $(\mathrm{p}=0,008)$ dan usia $(\mathrm{p}=0,021)$.

5) Selanjutnya dilakukan pengujian dengan regresi logistik berganda secara bersamaan dengan metode forward conditional untuk mengidentifikasi faktor paling berpengaruh terhadap keberhasilan ASI Eksklusif. Metode forward conditional yaitu memasukkan satu per satu variabel dari hasil pengkorelasian variabel dan memenuhi kriteria kemaknaan statistik untuk masuk ke dalam model, sampai semua variabel yang memenuhi kriteria tersebut masuk ke dalam model. Variabel yang masuk pertama kali adalah variabel yang mempunyai korelasi parsial terbesar dengan variabel dependen dan yang memenuhi kriteria tertentu untuk dapat masuk model. Korelasi parsial adalah korelasi antara 
variabel independen dengan dependen, kriteria variabel yang dapat masuk adalah 0,05 artinya variabel yang dapat masuk model bila variabel tersebut mempunyai nilai p lebih kecil atau sama dengan 0,05.

6) Hasil uji regresi logistik berganda menunjukkan bahwa sebanyak 1 variabel yang berpengaruh terhadap keberhasilan ASI Eksklusif yaitu pola makan, selengkapnya dapat dilihat pada tabel berikut.

Tabel 5. Hasil Uji Regresi Logistik Ganda

\begin{tabular}{lcccc}
\hline \multicolumn{1}{c}{ Variabel } & B & Sig. & $\operatorname{Exp}(\mathbf{B})$ & 95\% CI for $\operatorname{Exp}(\mathbf{B})$ \\
\hline Pola Makan & 2,565 & 0,006 & 13,000 & \multirow{2}{*}{$2,074-81,479$} \\
\hline Konstanta & $-1,609$ & 0,038 & 0,200 & \\
\hline
\end{tabular}

Berdasarkan hasil uji regresi logistik berganda tersebut nilai signifikan model secara bersama-sama diperoleh sebesar $0,038<0,05$ yang berarti bahwa satu variabel yang dijadikan model dalam penelitian ini memiliki pengaruh yang signifikan terhadap keberhasilan ASI Eksklusif.

Variabel yang berpengaruh dalam penelitian ini adalah variabel pola makan. Variabel pola makan mempunyai nilai $\operatorname{Exp}(\mathrm{B}) / \mathrm{OR}=13,000(95 \% \mathrm{CI}=2,074-81,479)$ artinya responden dengan pola makan teratur berpeluang berhasil dalam memberikan ASI Eksklusif sebesar 13 kali lebih tinggi dibandingkan responden dengan pola makan tidak teratur. Berdasarkan hasil uji regresi logistik berganda tersebut juga menunjukkan variabel yang tidak berpengaruh terhadap keberhasilan pemberian ASI eksklusif karena memiliki nilai signifikan $>0,05$ adalah variabel usia $(\mathrm{p}=0,108)$. Selengkapnya dapat dilihat pada tabel berikut.

Tabel 6. Hasil Uji Regresi Logistik Berganda yang Tidak Signifikan

\begin{tabular}{ccc}
\hline No. & Variabel & Sig. $($ p-value $)$ \\
\hline 1. & Usia & 0,108 \\
\hline
\end{tabular}

\section{CONCLUSION}

Berdasarkan hasil penelitian yang telah dilakukan dan disajikan pembahasan pada bab sebelumnya dapat disimpulkan bahwa:

1) Pola makan berpengaruh terhadap keberhasilan ASI Eksklusif di Puskesmas Langga Payung Kecamatan Sungai Kanan Kabupaten Labuhan Batu Selatan tahun 2020, $\mathrm{p}=0,008<0,05$. Variabel pola makan mempunyai nilai $\operatorname{Exp}(\mathrm{B}) / \mathrm{OR}=13,000(95 \% \mathrm{CI}=2,074-81,479)$ artinya responden dengan pola makan teratur berpeluang berhasil dalam memberikan ASI Eksklusif sebesar 13 kali lebih tinggi dibandingkan responden dengan pola makan tidak teratur.

2) Usia tidak berpengaruh terhadap keberhasilan ASI Eksklusif di Puskesmas Langga Payung Kecamatan Sungai Kanan Kabupaten Labuhan Batu Selatan tahun 2020, p = 0,108 > 0,05.

\section{Saran}

1. Dinas Kesehatan Kabupaten Labuhan Batu Selatan

a. Kepala Kesehatan Kabupaten Labuhan Batu Selatan membuat kebijakan atau peraturan tentang ASI eksklusif terutama bagi ibu yang bekerja.

b. Memberikan reward atau penghargaan kepada bidan atau puskesmas yang memiliki kinerja paling baik dalam peningkatan cakupan ASI eksklusif.

c. Membuat gerakan masyarakat 1000 hari pertama kehidupan (HPK) dan disosialisasikan di seluruh wilayah Kabupaten Labuhan Batu Selatan.

2. Puskesmas Langga Payung Kecamatan Sungai Kanan Kabupaten Labuhan Batu Selatan

a. Disarankan kepada kepala puskesmas untuk meningkatkan cakupan ASI eksklusif dengan memotivasi bidan desa untuk melakukan promosi kesehatan dan pendekatan kepada ibu hamil, ibu bersalin dan ibu menyusui terutama ibu yang bekerja.

b. Memberikan reward atau penghargaan pada bidan dengan kinerja terbaik dalam peningkatan cakupan ASI eksklusif.

3. Tenaga kesehatan (bidan)

Disarankan kepada Tenaga kesehatan (bidan) di Puskesmas Langga Payung Kecamatan Sungai Kanan untuk memberikan penyuluhan atau pendidikan kesehatan secara berulang-ulang kepada setiap ibu yang datang melakukan pemeriksaan kehamilan, bersalin serta melakukan home visite pada ibu menyusui untuk memberikan ASI saja sampai bayi berumur 6 bulan.

\section{REFERENCES}

Almatsier, S dan Susirah S. 2016. Gizi Seimbang Dalam Daur Kehidupan. Jakarta: Gramedia Pustaka Utama. Amiruddin, Ridwan. 2016. Promosi Susu Formula Menghambat Pemberian ASI Eksklusif pada bayi 6-11 Bulan di Kelurahan Pa'Baeng-Baeng Makassar. Skripsi. Makassar: Fakultas Kesehatan Masyarakat UNHAS. 
Erfiyani RI. 2020. Faktor Yang Berhubungan Dengan Perilaku Pemberian ASI Eksklusif di Kelurahan Pegirian Kecamatan Semampir Kota Surabaya. Medical Technology And Public Health Journal. 4(1): 24-32.

Fikawati, S., \& Syafiq, A. 2019. Penyebab Keberhasilan dan Kegagalan Praktik. Pemberian ASI Eksklusif. Kesmas, Jurnal Kesehatan Masyarakat Nasional.

Handajani, S. 2015. Pangan dan Gizi. Surakarta: Sebelas Maret University Press

Hoetomo. 2015. Kamus Lengkap Bahasa Indonesia. Surabaya: Mitra Pelajar.

Kemenkes RI. 2015. Kerangka Kebijakan Gerakan Sadar Gizi dalam Rangka Seribu Hari Pertama Kehidupan (1000 HPK). Jakarta : Direktorat Jenderal Bina Gizi dan Kesehatan Ibu dan Anak.

Kemenkes RI. 2016. Pedoman Gizi Seimbang. Jakarta: Direktorat Jenderal Bina Gizi dan Kesehatan Ibu dan Anak.

Kemenkes RI. 2017. Situasi dan Analisis Pendidikan Berdasarkan Usia. Jakarta: Kementerian Kesehatan Republik Indonesia.

Maryunani, Anik. 2017. Inisiasi Menyusui Dini, ASI Eksklusif dan Manajemen Laktasi. Jakarta: Trans Info Media (TIM).

Momongan, G.S, Doda V.D, Asrifuddin A. 2018. Hubungan Antara Umur Dan Durasi Kerja Dengan Pemberian ASI Eksklusif Oleh Ibu Pekerja Di Wilayah Kerja Puskesmas Ranotana Weru Kecamatan Wanea Kota Manado. Jurnal KESMAS. 7(5): 1-6.

Nina, Siti Mulyani. 2019. ASI dan Pedoman Ibu Menyusui. Yogyakarta: Nuha Medika.

Notoatmodjo, Soekidjo. 2016. Metodologi Penelitian Kesehatan. Jakarta: Rineka Cipta.

Novayelinda R. 2012. Telaah Literatur: Pemberian ASI dan Ibu Bekerja. Jurnal Ners Indonesia. 2(2): 1-8.

Nurkhasanah. 2016. ASI Atau Susu Formula. Jakarta : Flash Book

Nuswantari, Dyah. 2018. Kamus Kedokteran Dorland. Edisi 25. Jakarta: Penerbit Buku Kedokteran EGC.

Paramita, I. 2016. Hubungan antara Jenis Pekerjaan Ibu dengan Keberhasilan Pemberian ASI Eksklusif 6 Bulan Pertama di Puskesmas Rangkah Surabaya. Skripsi. Surabaya: Universitas Airlangga.

Pechlivani, et al. 2015. Prevalence and determinants of exclusive breastfeeding during hospital stay in the area of Athens, Greece. Acta Paediatrica, 2015; 94: 928-934

Prasetyono. 2016. Buku Pintar ASI Eksklusif. Yogyakarta: Diva Press.

Rahmawati, W., dan Wirawan N. N. 2016. Gizi untuk 1000 Hari Pertama Kehidupan. [serial online] [disitasi pada 20 Juli 2020]. Diakses dari URL : http://gizi.fk.ub.ac.id/sekilas-gizi-1000-hpk/.

Rejeki S. 2016. Studi Fenomenologi: Pengalaman Menyusui Eksklusif Ibu Bekerja di Wilayah Kendal Jawa Tengah. Media Ners. 2(1): 1-13.

Roesli, U. 2017. Mengenal ASI Eksklusif. Jakarta: Trubus Agriwidya.

Sanima, Utami NW, Lasri. 2017. Hubungan Pola Makan Dengan Produksi ASI Pada Ibu Menyusui Di Posyandu Mawar Kelurahan Tlogomas Kecamatan Lowokwaru Kota Malang. Nursing News. 2(3) : 154-163.

Setiowati, Tri. 2016. Hubungan faktor-faktor Ibu Dengan Pelaksanaan Pemberian ASI Eksklusif pada bayi 612 Bulan di Desa Cidadap Wilayah Kerja Puskesmas Pagaden Barat Kabupaten Subang Periode Januari-Juli 2011. Jurnal Kesehatan. 2(1): 45-53.

Suhardjo. 2017. Berbagai Cara Pendidikan Gizi. Jakarta. Bumi Aksara

Sulistyoningsih, H. 2016. Gizi Untuk Kesehatan Ibu dan Anak. Yogyakarta: Graha Ilmu.

Sulistiyowati, T dan Siswantara P. 2014. Perilaku Ibu Bekerja Dalam Memberikan Asi Eksklusif Di Kelurahan Japanan Wilayah Kerja Puskesmas Kemlagi-Mojokerto. Jurnal Promkes, 2(1): 89-100.

\section{BIOGRAPHIES OF AUTHORS}

\begin{tabular}{|l|l|}
\hline Debora Lestari Simamora, Gelar D-III diperoleh dari Akademi Kebidanan Imelda \\
Medan, Jurusan Kebidanan pada tahun 2009. Gelar Sarjana diperoleh dari Poltekes \\
Kemenkes RI Medan, Jurusan Bidan Pendidik Tahun 2011. Magister Kesehatan \\
diperoleh dari Universitas Sumatera Utara, Jurusan Kesehatan Reproduksi pada tahun \\
2017. Saat ini aktif sebagai dosen tetap di Prodi D-III Kebidanan Universitas Imelda \\
Medan.
\end{tabular}

